\title{
NOTE
}

\section{A tropical bird in the Arctic (the cormorant paradox)}

\author{
David Grémillet $^{1, *}$, Rory P. Wilson ${ }^{2}$, Sarah Wanless ${ }^{1}$, Gerrit Peters ${ }^{2}$ \\ ${ }^{1}$ Institute of Terrestrial Ecology, Banchory Research Station, Hill of Brathens, Glassel, Banchory AB31 4BY, Scotland, UK \\ ${ }^{2}$ Institut für Meereskunde Kiel, Abteilung Meereszoologie, Düsternbrooker Weg 20, 24105 Kiel, Germany
}

\begin{abstract}
Seabirds, like all marine endotherms, have to compensate for the extensive cooling effect of water when diving. Alone among them, cormorants (Phalacrocoracidae) have a wettable plumage and are predicted to require disproportionately large amounts of food to balance heat losses. These piscivorous birds are thus thought to have a detrimental impact on fish stocks. However, we show here that even in great cormorants from Greenland, which dive in water at 3 to $7^{\circ} \mathrm{C}$, daily food intake is lower than for well-insulated European seabirds. Despite their wettable plumage, cormorants thus appear to manage their energy budgets in a remarkably efficient way. Nevertheless, the specific foraging strategies which enable this performance make cormorants dependent on high prey density areas, a feature that should be taken into account by future management plans.
\end{abstract}

KEY WORDS: Diving endotherms - Cormorants - Insulation Food requirements Prey

The ancestors of contemporary diving endotherms (seabirds and marine mammals) faced major adaptative challenges as they returned to a semi- or fully aquatic lifestyle some 50 to 30 million years ago. In particular, the high thermal conductivity of water compared to air led to a series of adaptations regarding insulation, for example thick layers of sub-cutaneous fat, water-proof fur and plumage. A remarkable exception to this can be found in cormorants (Phalacrocoracidae), diving birds whose plumage is wettable (Rijke 1968). Consequently, heat loss to the water, daily food requirements and predation pressure on prey stocks are all thought to be proportionately higher in great cormorants than in other diving endotherms (Draulans 1988). Present concerns regarding the potentially detrimental effect of the great cormorants Phalacroco-

•E-mail: d.gremillet@ite.ac.uk rax carbo, and of the closely related double-crested cormorant $P$. auritus, on commercial fish populations throughout Europe and Northern America exemplify this (Glahn \& Brugger 1995, Kirby et al. 1996). However, recent investigations of great cormorants breeding in Normandy showed that the food requirements of these birds were surprisingly low when compared to other (fully water-proof) seabirds from the same climatic zone (Grémillet 1997, Grémillet \& Argentin 1998). A reason for this may be that, far from being archaic, plumage wettability in cormorants represents an excellent adaptation to diving in shallow, temperate waters (Lovvorn \& Jones 1991, Wilson et al. 1992). The plumage, which is only partially permeable and thus keeps a thin insulating air layer at the water/skin interface (Grémillet et al. 1998a), enables the birds to become water-logged and to manoeuvre easily at depths without incurring buoyancy problems as do diving ducks, which are vigorously pushed back to the water surface (Wilson et al. 1992). This adaptation is appropriate as long as the birds hunt in relatively warm, shallow waters, and, not surprisingly, the cormorants' radiation started some 34 million years ago from tropical lagoons (Mourer-Chauviré 1982). Subsequently, this extremely cosmopolitan bird family has scattered over all 6 continents, with the breeding range of great cormorants extending from equatorial Africa to the high Arctic (Fig. 1; Johnsgard 1993, Russell et al. 1996) while that of double-crested cormorants extends from Cuba to Alaska (Johnsgard 1993). However, minimal body insulation is at odds with the survival of these birds through the European and North American winter or when breeding at high latitudes, as energy costs of swimming may then be $600 \%$ higher than during the European summer (Grémillet et al. 1998a). We infer that these situations should at least lead to increased fish consumption to compensate for and recognise concerns about the 


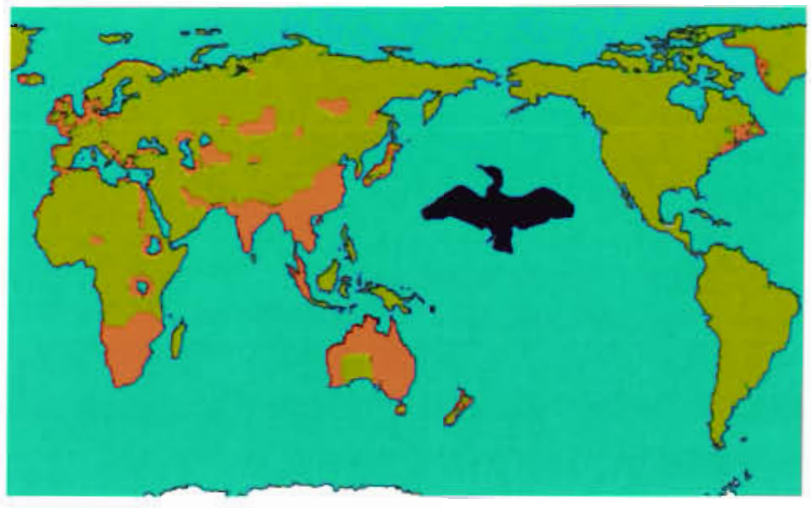

Fig. 1. Distribution of the breeding populations (red areas) of the great cormorant Phalacrocorax carbo adapted from Johnsgard (1993) and Russell et al. (1996)

detrimental influence of wintering great cormorants and double-crested cormorants on European and North American commercially important fish stocks (Suter 1995). To examine this problem, we studied the feeding ecology of the northernmost great cormorant population on Disko, West-Greenland, where the birds routinely dive in water at less than $5^{\circ} \mathrm{C}$.

Materials and methods. Great cormorants raising chicks were studied under permit in June and July 1998 at Qeqertaq Island, Disko, West-Greenland $\left(69^{\circ} 30^{\prime} \mathrm{N}, 54^{\circ} 05^{\prime} \mathrm{W}\right)$, with automated nest-balances recording the total nest mass (Grémillet et al. 1996). Using the body mass variation of male and female birds as measured at the nest site before and after feeding, the mass of each food load brought back to the nest was calculated (Grémillet et al. 1996). All birds studied were additionally fitted with radio-transmitters (18 g, $30 \mathrm{~mm}$ long, $20 \mathrm{~mm}$ diameter) and stomach temperature loggers $(16 \mathrm{~g}, 69 \mathrm{~mm}$ long, $16 \mathrm{~mm}$ diameter) in order to determine their activity patterns at sea (see Grémillet et al. 1998b) as well as the mass of the individual prey items (see Grémillet \& Plös 1994). These data were used to correct food load mass for the influence of at-sea digestion via an algorithm given in Grémillet et al. (1996). Corrected food loads were then summed to calculate the daily food intake of individual birds to the nearest $20 \mathrm{~g}$.

Surface water temperature (which was assumed to be highest within the water column at this point) was measured to the nearest $0.1^{\circ} \mathrm{C}$ throughout the study period at the birds' feeding area (which was also determined via radio-tracking).

Brood biomass was determined by weighing the chicks to the nearest $25 \mathrm{~g}$ at the beginning and at the end of the experiment (typically lasting $8 \mathrm{~d}$ ). In order to avoid further disturbance, daily chick masses between the first and the last day of the experiment were back calculated using a growth curve after Dunn (1976). The daily food intake (DFI, g) of adult birds was then corrected for the influence of body mass (BM in grams) and allometric discrepancies via:

$$
D F I_{\text {corr }}=\left(\frac{D F I}{B M}\right)^{0.75}
$$

where $\mathrm{DFI}_{\text {corr }}$ is the corrected DFI $(\mathrm{g})$, and related to current brood biomass.

We then used general linear models to compare the effect of brood biomass on standardised DFI between sexes and between 2 locations: (1) Disko Island (this study); and (2) Normandy, where JJFI was measured for the same sub-species (Phalacrocorax carbo carbo) and using the same methodology (Grémillet 1997), but for birds diving in water at 12 to $15^{\circ} \mathrm{C}$ (Fig. 2).

This comparison takes into account that birds were breeding successfully in both study areas and that their BMs (which were assessed daily using our weighing data) remained constant throughout the study.

The strongest relationships were found to occur between standardised daily food intake and brood biomass, and it is these regressions that are presented (Fig. 2).
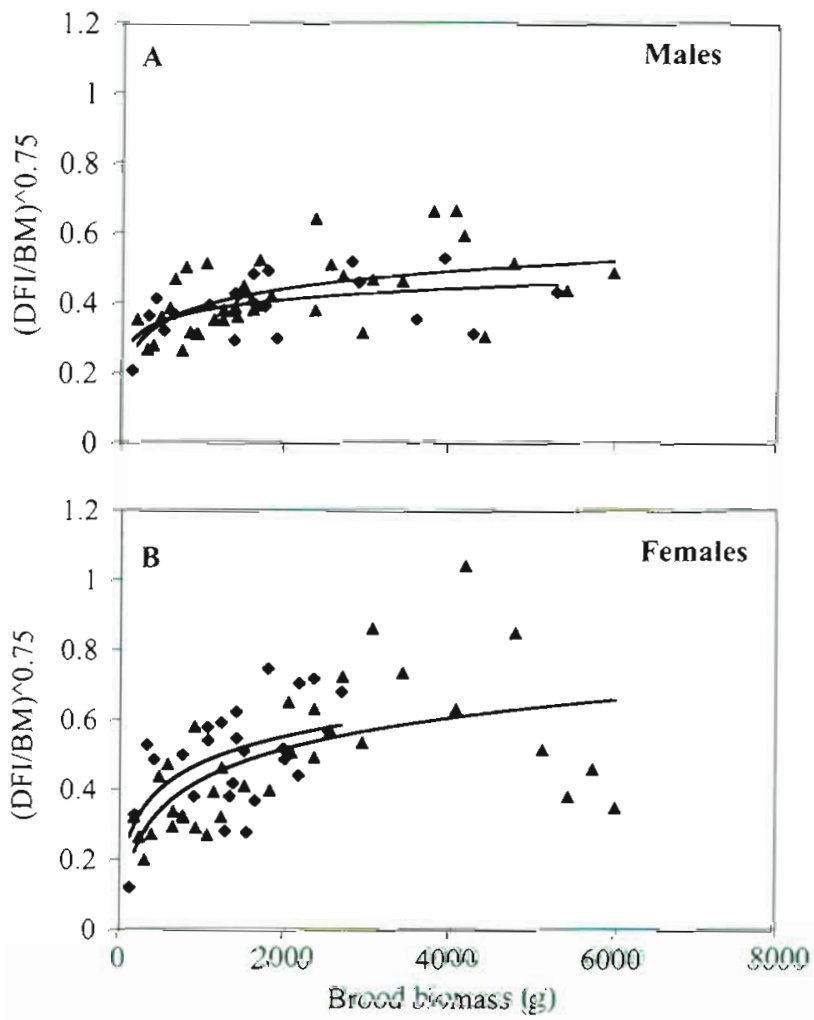

Fig. 2. Mass-specific daily food intake (DFI) as a function of brood biomass in (A) male and (B) female great cormorants breeding in Normandy ( $\bullet$ ) and on Disko, Greenland ( 4 ). Males in Normandy: $F=5.9, p<0.05$; males on Greenland: $F=16.1, \mathrm{p}<0.001$; females in Normandy: $F=10.2, \mathrm{p}<0.005$; females on Greenland: $F=19.7 ; p<0.001 . B M=$ body mass 
Furthermore, the daily food requirements of great cormorants from Normandy and Greenland were compared with those of 11 other seabird species from the North Sea (northern fulmar Fulmarus glacialis, BM = $730 \mathrm{~g}$; Manx shearwater Puffinus puffinus, $\mathrm{BM}=370 \mathrm{~g}_{\mathrm{i}}$ northern gannet Sula bassana, $\mathrm{BM}=2570 \mathrm{~g}$; great skua Catharacta skua, BM $=1160 \mathrm{~g}$; European shag Phalacrocorax aristotelis, BM $=1620 \mathrm{~g}$; Arctic skua Stercorarius parasiticus, BM $=350$ g; herring gull Larus argentatus, $\mathrm{BM}=920 \mathrm{~g}$; black-legged Kittiwake Rissa tridactyla, $\mathrm{BM}=310 \mathrm{~g}$; razorbill Alca torda, $\mathrm{BM}=$ $590 \mathrm{~g}$; guillemot Uria aalge, $\mathrm{BM}=770 \mathrm{~g}$; and puffin Fratercula arctica, BM $=330 \mathrm{~g}$ ). To this end, DFI in non-breeding great cormorants from Normandy and Greenland was derived from relationships shown in Fig. 2, with brood biomass being zero. Calculations regarding further non-breeding seabirds from the North Sea were based on allometric relationships and followed Bryant \& Furness (1995) and Garthe et al. (1996).

Results. DFI was measured for 11 birds $(6$ males and 5 females) breeding on Greenland over a period of 5 to $10 \mathrm{~d}$. Water temperature at the feeding sites varied between 3 and $7^{\circ} \mathrm{C}$ during the study period. Significant relationships were found in both sexes between mass specific daily food intake and brood biomass (Fig. 2).

Overall, there was a significant difference between sexes, with females responding to increasing brood biomass by a sharper increase in food intake (slopes are significantly different, $F=4.92, \mathrm{p}<0.05$, Fig. 2). However, neither in males nor in females was there any significant difference between data collected in Normandy and in Greenland (similar slopes $F=0.95$, $\mathrm{p}>0.10$ and similar intercepts $F=0.72, \mathrm{p}>0.10$ in males; similar slopes $F=0.15, \mathrm{p}>0.50$ and similar intercepts $F=0.26, \mathrm{p}>0.50$ in females; Fig. 2A,B). Great cormorants studied in Normandy mainly fed on labrids, with an approximate energy content of $4 \mathrm{~kJ} \mathrm{~g}^{-1}$ (Grémillet \& Argentín 1998). On Greenland, preliminary analysis (Grémillet et al. unpubl. data) showed that great cormorants take large numbers of sea scorpions (Cottidae), with an average energy density of $3.8 \mathrm{~kJ} \mathrm{~g}^{-1}$ (Grant 1984, unpubl. data). Both locations thus provide great cormorants with food of equivalent energetic value, so that a comparison based on food mass remains correct. Both estimates of DFI in great cormorants from Greenland and Normandy lay well below predicted values for other seabird species from the North Sea (Fig. 3).

Discussion. Our results show that, despite the markedly lower water temperatures, there was no evidence of a higher mass-specific DFI among the Greenland birds. Moreover, mass-specific DFI of great cormorants breeding in Normandy and on Greenland was low relative to the DFI of well-insulated, diving or nondiving European seabirds (Fig. 3).

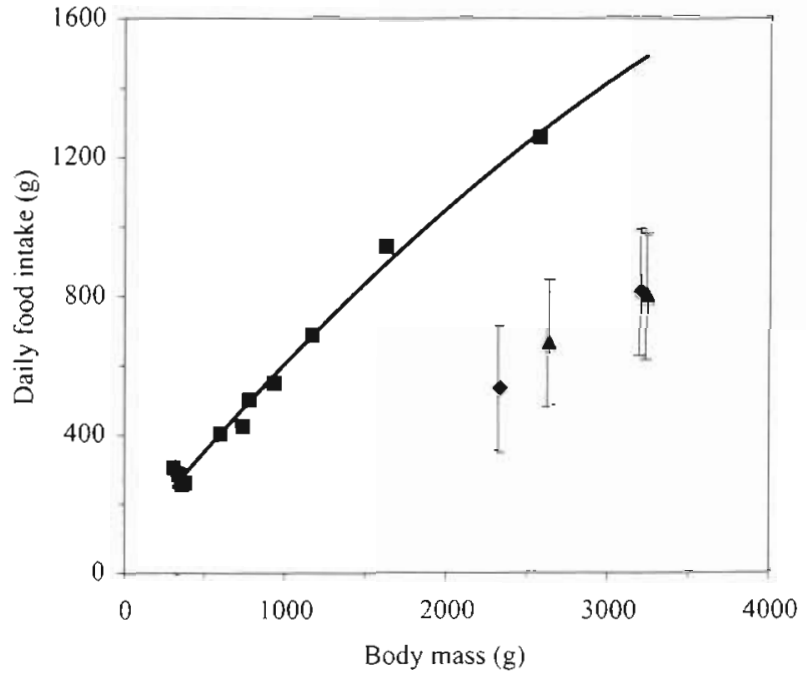

Fig. 3. Comparison of estimated daily food intake of nonbreeding great cormorants from Normandy ( $\bullet: 95 \% \mathrm{Cl}$, male and female body mass is 3200 and $2330 \mathrm{~g}$, respectively), from Greenland ( $195 \% \mathrm{Cl}$, male and female body mass is 3240 and $2630 \mathrm{~g}$, respectively) and in 10 other seabird species from the North Sea outside the breeding season (

Current research on diving endotherms largely focuses on energy costs and their relationship to species-specific diving performance and environmental characteristics (de Vries \& van Eerden 1995, Butler \& Jones 1997). Viewed in this way, diving endotherms appear to have an energetically costly way of life, especially if they are poorly insulated like cormorants. However, benefits (energy acquisition via prey intake) are usually overlooked.

In the case of cormorants, there are 2 potential mechanisms which could reduce energy costs: (1) Morphological adaptation: although plumage wettability has been confirmed throughout the great cormorants' range (Mahoney 1984, Wilson et al. 1992) birds may respond to cold weather conditions by enhanced fat reserves and increased body mass; and (2) Physiological adaptation: the rate of heat loss to the water is directly related to the temperature differential between the bird's body and the water. Therefore, birds may reduce heat loss by allowing their body temperature to decrease during the time spent diving in cold water. This response has been already demonstrated in the bank cormorants Phalacrocorax neglectus (Wilson \& Grémillet 1996) and the blue-eyed shags $P$. atriceps (Bevan et al. 1997).

However, although these adaptations can reduce the total energy demand to some extent, modelling studies (Grémillet \& Wilson in press) indicate that their overall impact on the cormorants' energy balance is over 1 order of magnitude lower than that of ecological and behavioural adaptations which serve to maximise rates 
of energy gain and thus minimise the time spent diving in a challenging environment. These behavioural patterns may involve special diving techniques (Grémillet et al. 1998b) which enable great cormorants breeding in temperate Normandy to display the highest preycatching rates measured to date in seabirds (Grémillet 1997). These birds thus easily compensate for heat loss to water at $12^{\circ} \mathrm{C}$. However, diving competence per se is unlikely to improve radically in birds exposed to extreme weather conditions. We therefore postulate that it is rather the selection of particularly energy-rich prey species and/or high densities which will enable cormorants from Greenland to minimise the time spent hunting in cold water. The fact that predator ecology is tightly linked to prey patch density and quality is not new (Stephens \& Krebs 1986). However, modelling studies showed that cormorants lose heat at such a high rate when diving that a decrease of only $25 \%$ in prey density, and the resulting increase in time spent diving for fish, may result in a $100 \%$ increase in DFI (Grémillet \& Wilson in press). Cormorants may thus have a low DFI compared to other seabirds (Fig. 3), even when wintering on Greenland or in the American Arctic, but we predict that their distribution will be tightly linked to areas of high prey density and/or quality throughout the year.

With regard to current management plans of the rapidly growing great cormorant and double-crested cormorant populations in Europe and North America, respectively (Hatch 1995, Russell et al. 1996), we recommend cognisance of the ability of these birds to utilise a wide range of abiotic conditions as well as their reliance on high prey densities and/or quality when modelling their potential influence on commercial fish stocks. We anticipate that these birds will be unable to utilise prey below a certain density during the winter period, making them incapable of decimating specific prey stocks, as has often been claimed (Carss \& Marquiss 1995). In this situation, an efficient management strategy would be to keep stocking densities of commercially important fish at a level lower than that required by cormorants to meet their energy demands (Kirby et al. 1996).

Acknowledgements. We are particularly thankful to R. Dey, J. M. Jensen, N. Pekruhl and M. Krause for their courageous help during fieldwork. This study was supported by the Institut für Meereskunde Kiel, the Alfred Wegener Institut für Polar und Meeresforschung and via a TMR Marie Curie grant (ERBFMBICT982888) to D.G. We thank the Greenland Homerule Government, the Arktisk Station, the Danish Polar Center, the Greenland Homerule Authority (Ministry of Health and Research) and the Danish Veterinary and Food Administration for permission to conduct this study in protected areas on Disko and for logistic support. Grateful thanks for the extensive help provided throughout the study by $D$. Boertmann from the National Environmental Research Insti- tute, Denmark, the people of Kangerluk, R. Kristensen, H. A. Thomsen, J. Nymand, H. Ahammer and A. Weippert. Special thanks are due to $F$. Nielsen and to the crew of the RS 'Porsild' D.G. thanks D. Adelung, S. Hochscheid, his colleagues at the IFM Kiel and the FTZ Büsum, D. Elston (BioSS) and $\mathrm{H}$. Drews. This work is dedicated to M. P. Harris on the occasion of his retirement from ITE Banchory.

\section{LITERATURE CITED}

Bevan RM, Boyd IL, Butler PJ, Reid K, Woakes AJ, Croxall JP (1997) Heart rates and abdominal temperatures of freeranging South Georgian shags, Phalacrocorax georgianus. J Exp Biol 200:661-675

Bryant DM, Furness RW (1995) Basal metabolic rates of North Atlantic seabirds. Ibis 137:219-226

Butler PJ, Jones DR (1997) Physiology of diving of birds and mammals. Physiol Rev 77:837-899

Carss D, Marquiss M (1995) Fish-eating birds: perceptions and 'realities'. Proc Br Trout Farming Conf 95:33-47

de Vries J, van Eerden MR (1995) Thermal conductance in aquatic birds in relation to the degree of water contact. body mass, and body fat: energetic implications of living in a strong cooling environment. Physiol Zool 68:1143-1163

Draulans D (1988) Effects of fish-eating birds on freshwater fish stocks: an evaluation. Biol Cons 44:251-263

Dunn EH (1976) Development of endothermy and existence energy of nestling double-crested cormorants. Condor 78: $350-356$

Garthe S, Camphuysen CJ, Furness RW (1996) Amounts of discards by commercial fisheries and their significance as food for seabirds in the North Sea. Mar Ecol Prog Ser 136 $1-11$

Glahn JF, Brugger KE (1995) The impact of double-crested cormorants on the Mississippi Delta catfish industry: a bioenergetics model. Colon Waterbirds 18:168-175

Grant DAD (1984) SIS industrial training report. Unpubl report, Institute of Terrestrial Ecology, Banchory

Grémillet D (1997) Catch per unit effort, foraging efficiency and parental investment in breeding great cormorants (Phalacrocorax carbo carbo). ICES J Mar Sci 54:635-644

Grémillet D, Argentin G (1998) Cormorants, shags and fisheries in the Chausey Island area. Le Cormoran 47:196-202

Grémillet D, Plös A (1994) The use of stomach temperature records for the calculation of daily food intake in cormorants. J Exp Biol 189:105-115

Grémillet D, Wilson RP (in press) A life in the fast lane: energetics and foraging strategies on the Great Cormorant. Behav Ecol

Grémillet D, Dey R, Wanless S, Harris MP, Regel J (1996) Determining food intake by great cormorants and European shags with electronic balances. J Field Ornithol 67 : $637-648$

Grémillet D, Tuschy I, Kierspel M (1998a) Body temperature and insulation in diving great cormorants and European shags. Funct Ecol 12:386-394

Grémillet D, Argentin G, Schulte B, Culik B (1998b) Flexible foraging techniques in breeding cormorants Phalacrocorax carbo and shags Phalacrocorax aristotelis: benthic or pelagic feeding? Ibis 140:113-119

Hatch JJ (1995) Changing populations of double-crested cormorants. Colon Watervirds 18:8-24

Johnsgard PA (1993) Cormorants, darters and pelicans of the world. Smithsonian Institution Press, Washington, DC, p 226-234

Kirby JS, Holmes JS, Sellers RM (1996) Cormorants Phalacro- 
corax carbo as fish predators: an appraisal of their conservation and management in Great Britain. Biol Cons 75 : 191-199

Lovvorn JR, Jones D (1991) Body-mass, volume, and buoyancy of some aquatic birds, and their relation to locomotion strategies. Can J Zool 69:2888-2892

Mahoney SA (1984) Plumage wettability of aquatic birds. Auk 101:181-185

Mourer-Chauviré C (1982) Les oiseaux fossiles des Phosphorites du Quercy (Eocène supérieur à Oligocéne supérieur): implications paléobiogéographiques. Geobios Mem Spec $6: 413-426$

Rijke AM (1968) The water repellency and feather structure of cormorants. J Exp Biol 48:185-189

Russell IC, Dare PJ, Eaton DR, Armstrong JD (1996) Assessment of the problem of fish-eating birds in inland fisheries

Editorial responsibility: Otto Kinne (Editor),

Oldendorf/Luhe, Germany in England and Wales (Ministry of Agriculture, Fisheries and Food [MAFF] project report VC0104). MAFF, Lowestoft

Stephens DW, Krebs JR (1986) Foraging theory. Princeton University Press, Princeton, p 13-36

Suter W (1995) The effect of predation by wintering cormorants Phalacrocorax carbo on grayling Thymallus thy mallus and trout (Salmonidae) populations: two case studies from Swiss rivers. J Appl Ecol 32:29-46

Wilson RP, Grémillet D (1996) Body temperature of free-living African penguins (Spheniscus demersus) and bank cormorants (Phalacrocorax neglectus). J Exp Biol 199 $2215-2223$

Wilson RP, Hustler K, Ryan PG, Burger AE, Nöldecke EC (1992) Diving birds in cold water: do Archimedes and Boyle determine energetic costs? Am Nat 140:267-275

Submitted: April 12, 1999; Accepted: July 16, 1999

Proofs received from author(s): October 11, 1999 